UDK: 37.016/.017

Original scientific paper

\title{
PEDAGOGICAL DISCOURSE OF CURRICULUM DEVELOPMENT BASED ON THE ORIENTATION OF EDUCATIONAL PRACTICE
}

Šejla Bjelopoljak

Faculty of Education

University of Bihać

Bosnia and Herzegovina

bjelopoljaksejla@hotmail.com

Arijana Midžić

Faculty of Education

University of Bihać

Bosnia and Herzegovina

ari_jana_91@windowslive.com 


\section{ABSTRACT}

Education reform that follows the needs of all students, parents and employees in educational institutions would imply goal-oriented action. The practice that promotes a concept focused on the teaching content and which does not even announce the learning outcomes in the pedagogical records confirms that the student is not a subject of the educational process and that there is a possible gap between theory and practice. However, what if we see this realization as a possibility?

If we started the analysis of the quality of practice orientations and "from the end," we would determine the factual role of all those involved in the educational process without, possibly unnecessary, polar orientations "for and against".

The aim of this paper is to examine the orientation of the curriculum present in the practice of educational institutions in order to conclude about the pedagogical discourse as the basis for change. The paper first operationalizes the concepts with regard to the types of curriculum present in educational practice, and then empirically verifies the testing of the set hypotheses. The obtained research results show that all curriculum orientations are equally represented in educational practice; classroom and subject teachers do not differ in the implementation of the educational process according to the type of curriculum and the orientation to learning outcomes and teaching goals contribute to the explanation of the open and closed curriculum. The last part of the paper explains and critically discusses pedagogical discourse as an agent for changes in the field of educational practice quality based on initial reflections on the current focus on competencies as a pedagogical standard. The contribution to the research was given by 113 educators employed in primary schools by providing answers to the created e-Instrument for the purpose of the research.

Key-words: pedagogy, curriculum, teaching goals, educational outcomes, pedagogical discourse. 


\section{INTRODUCTION}

\section{There are worlds between teaching goals and educational outcomes.}

Regarding the polarized opposition of teaching goals and educational outcomes, we infer a problematic understanding of positions in which the necessary commitment is implicitly proclaimed as focused on the student, teacher, teaching content, multimedia or something else in the face of pedagogy. The primary orientation neglects a holistic approach in which it is possible to reconcile the demands that meet the needs of students, but at the same time those that society puts before them. This possibility of comprehension is inspired by the practices of subversive individuals, educators who change worlds in their classroom environments and seem to ignore the content of the curriculum while planning work that meets the needs of the child. How do they achieve that? Is it because of the orientation towards teaching goals or educational outcomes or something that does not require commitment: creating a pedagogical environment in which the learning worlds of students and teachers will take place, without excessive hegemony of one of the parties. In accordance with the above, in the research part of the paper we will analyze the current orientations of the curriculum (still implicit) present in educational work, while considering the synthesis of recommendations that link different orientations, in order to mediate between simplified (alternative, exclusive) views the position of the factors of the educational process or the goals we strive for based on teaching or educational outcomes.

The social transformation of the personality of the educator and the child in the educational process should be planned in advance, which would justify the responsibility of the teaching employees when pre-planning and choosing curriculum orientations with which to achieve the expected educational result. The paper plans empirical verification and analysis of different approaches in practice that determine the goal of curriculum orientations (when in ideal conditions it is explicit and uniform), which is why we will first operationalize the concepts in order to uniformly understand the assumptions of future practice and possible pedagogical discourse.

The essence of different definitions (Slunjski, 2001; Slunjski, 2010; Kessler, Swadener, 1992; Bjelopoljak, Redžić, 2020) lead in the direction of openness and closedness, as well as distinctions of the terms (1) transmission, (2) transactions and (3) transformations. Operationalization of concepts implies (1) "teaching, interpretation and balancing of subject areas, by thinking about means of motivating students, teaching techniques, and all that can be planned in advance" 
(Kessler, Swadener, 1992, 94). This type of practice is present in the educational work of school institutions, especially in cases of measuring reproduction and memorizing the amount of information / mastered content. (2) It implies a more open approach in which we reflect on the essence of education, plan outcomes based on the needs of students, which through research teaching lead to the essence of understanding what has been learned "... Education is actually a dialogue between students, i.e. children and the curriculum, in which children constantly reconstruct knowledge (...), a central element of this approach is the emphasis on problem-solving strategies (...) and the application of problem-solving skills in a social context (...) and the development of cognitive skills in within certain academic disciplines!" (Kessler, Swadener, 1992, 94). We notice that this type of practice in educational work stands out under the sound titles of the phrase "examples of good practice" without the practice always being so - for all those who sometimes make a step towards meeting the needs of children who inevitably demand enjoyment of school learning. (3) Unlike the traditionally understood role of the educator who "teaches" content to children, and transmits ready-made information that needs to be memorized, this approach starts from Freire's idea that no one can present the problem to another person while remaining a mere observer. Understanding a problem situation, reveals to the other new ways of understanding the problem being analyzed. In this way, the educator constantly "sees again" the problematic object that the child "sees," so he never stops learning (Freire, 1993; as cited in Slunjski, 2001). This type of open curriculum thematically plans the processing of content that arouses the desire to learn and most directly describes Tillmann's understanding of the role of school to determine the purpose of our pedagogical approach by the formation of school learning (Tillmann, 1994), i.e. by planning a stimulating learning environment in which an educational result will inevitably occur with the intention of an adult, whether it is a consequence of an interpersonal relationship or a dialogue between students and content with the occasion. 


\section{RESEARCH METHODOLOGY}

\section{About the problem and the research subject}

The prevailing understanding of educational practice is that ideal educational work occurs when it is based on the students' needs. If it is not provided with systemic support in accordance with the current education reform, the remaining option is the implementation of the curriculum as the only normative act that describes the teaching process and then it is based on teaching goals - due to the original focus on teaching content. Even in such conditions, there is a different perception of the essence of school learning and the role of the teaching employees. Some of the reasons are: different starting positions of educators (especially when it comes to knowledge achieved through initial education), uneven investment of systemic and co-curricular support (activities offered for the growth and development of educators "from outside" correspond to professional development, but are initiated by individuals or non-governmental organizations) in only some parts of the educational system, professional development of the educator left to personal motivation, etc. Such disparate support results in the practice of different perceptions of the essence of school learning, the identity of the educator and the current "futuristic idea" of investing in an alternative to one of the two imposed choices: teaching style based on teaching goals or teaching outcomes, guided by the educational outcomes of student needs. In order to understand the different approaches, they need to be researched so as to conclude on the goal that determines the orientation of the curriculum. The research subject will be transferred to the "pedagogical discourse of curriculum development based on the orientations of educational practice" discussions in the context of an idea or philosophy (according to Klajić, 1986), so we present a critical analysis of the pedagogical discourse in the form of recommendations based on the obtained finding in support of the fourth research hypothesis.

\section{The aim of the research}

Examine the orientation of the curriculum present in the practice of educational institutions and conclude on the pedagogical discourse as the basis for change.

\section{Research tasks}

1.Examine current curriculum orientations in educational practice;

2. Examine whether teachers working in class and subject teaching differ in the implementation of the educational process according to the type of curriculum; 
3. Examine the relationship of orientations to educational outcomes and teaching goals and curriculum type.

4. Propose recommendations in order to improve educational work through a critical perspective of pedagogical discourse.

\section{Hypotheses}

H1: There is a representation of all types of curriculum in the educational practice of the represented sample;

H2: Class and subject teachers do not differ in the implementation of the educational process according to the type of curriculum;

H3: Orientation to educational outcomes and teaching goals is expected to contribute to the explanation of open and closed curriculum;

H4: Recommendations given as measures of improvement through the perspective of pedagogical discourse enable the reduction of the gap between polarised orientations focused on the position of the factors of the educational process.

\section{Research sample}

The sample is random. It includes a total of $\mathrm{N}=113$ teaching employees that implemented the educational process in primary and secondary schools in the school year 2020/21 and who supported the idea of questioning the quality of the current practice. A more detailed tabular presentation of the characteristics of the research sample expressed in frequencies is presented in Table 1.

Table 1. Characteristics of the research sample

\begin{tabular}{ccc}
\hline Sample description & N & $\%$ \\
\hline The whole sample & 113 & \\
\hline Teachers in the class & 65 & 57.52 \\
\hline Teachers in subject teaching & 48 & 42.48 \\
\hline
\end{tabular}

\section{Research method}

The combination of qualitative and quantitative research approach discussed by the authors (Sekol, Maurović, 2017), with the help of descriptive and theoretical analysis methods, will present a qualitative interpretation of research results, and survey and evaluation procedures will examine the orientation of the curriculum in educational institutions.

The descriptive method was chosen due to the need to select sources on curricular theories and pragmatism of work in educational institutions based 
on observed pedagogical discourse, whereas theoretical analysis methods were employed due to the general and professional-theoretical orientation literature in the field of development of pedagogy and application of curricular theories. By combining the procedures of survey and assessment / judgment, an e-Instrument for examining the orientation of the curriculum in educational institutions had been created. After the introductory part of the Instrument dedicated to instructions for completing / responding and characteristics of the sample, there are subscales of orientation assessment in the form of basic dimensions. The dimensions are: the role / position of the educator, planning, teaching, learning, evaluation and types of curriculum. Each of the dimensions consists of a uniform number of questions / statements answered on a Likert scale from 1 - no to 5 - always.

Opinions and attitudes are grouped in the common variables "open" and "closed curriculum" in accordance with research tasks and hypotheses. According to the obtained results, the scale for assessing the orientation of the curriculum has a good internal agreement for this sample and reliability based on the obtained Cronbach's alpha coefficient is 0.735 .

\section{Data processing methods}

IBM SPSS Statistics 21 was used to process the data. Descriptive statistics procedures were used to represent the sample and the expressiveness of the variables, regression analysis was used to examine the influence between the variables, and the Mann-Whitney $U$ test was used to determine the differences. 


\section{ANALYSIS AND DISCUSSION OF ACHIEVED RESULTS}

\section{Current curriculum orientations in educational practice}

Table 2 presents the obtained results that speak in favor of equally represented types of curriculum in educational practice with regard to the role/position of the educator and other subscales: planning, teaching, learning, evaluation and type of curriculum.

Table 2. Overview of curriculum orientations in educational practice

\begin{tabular}{|c|c|c|c|c|}
\hline $\begin{array}{l}\text { Instrument } \\
\text { dimensions }\end{array}$ & Attitudes / claims & $\begin{array}{c}\text { Respondents' } \\
\text { answers }\end{array}$ & f & $\%$ \\
\hline \multirow{6}{*}{$\begin{array}{l}\text { The role/position } \\
\text { of the educator }\end{array}$} & $\begin{array}{l}\text { I am a member of the needs research and project } \\
\text { development team at the institution where I work. }\end{array}$ & No & 78 & 69 \\
\hline & $\begin{array}{l}\text { Last year, I presented a demonstration class to my } \\
\text { colleagues. }\end{array}$ & No & 62 & 54.9 \\
\hline & $\begin{array}{l}\text { I used online teaching except for teaching the } \\
\text { teaching content and for interconnecting students } \\
\text { through tasks that are not related to the teaching } \\
\text { content. }\end{array}$ & Yes & 95 & 84.1 \\
\hline & $\begin{array}{l}\text { I am motivated to change the practice of the } \\
\text { educational process and system. }\end{array}$ & Yes & 111 & 98.2 \\
\hline & $\begin{array}{l}\text { I am satisfied with the interpersonal relationships } \\
\text { in my team. }\end{array}$ & Yes & 61 & 54 \\
\hline & $\begin{array}{l}\text { I am supported by the school management when } \\
\text { I propose ideas that innovate the educational } \\
\text { process. }\end{array}$ & Yes & 84 & 74.3 \\
\hline \multirow{6}{*}{ Planning } & $\begin{array}{c}\text { In my teaching preparation I have a clearly } \\
\text { stated goal through tasks (material, functional, } \\
\text { educational). }\end{array}$ & Yes & 105 & 92.92 \\
\hline & $\begin{array}{l}\text { I use old preparations sometimes because the } \\
\text { curriculum does not change. }\end{array}$ & Sometimes & 53 & 46.9 \\
\hline & $\begin{array}{l}\text { The form of preparation I use does not provide for } \\
\text { writing learning outcomes. }\end{array}$ & No & 76 & 67.25 \\
\hline & $\begin{array}{l}\text { I am involved in the process of creating or } \\
\text { changing the curriculum. }\end{array}$ & No & 96 & 84.95 \\
\hline & $\begin{array}{l}\text { I have attended professional development on the } \\
\text { topic of curriculum. }\end{array}$ & No & 76 & 67.25 \\
\hline & $\begin{array}{l}\text { I am sure that the curriculum is not the same as } \\
\text { the teaching plan and programme. }\end{array}$ & Yes & 69 & 61.06 \\
\hline
\end{tabular}


Teaching content is appropriate for the age, individual needs of students and their previous Sometimes $45 \quad 39.80$ experience.

I use various creative techniques in teaching (KWL causal and / or pro-pro model, essay with $\quad$ Yes $\quad 73 \quad 64.60$ argumentation, T-table, Venn diagram ...)

In teaching, I used information and communication technologies (Zoom, GClass, Meet, web tools) even before conducting online No $\quad 82 \quad 72.56$ classes.

I teach students to design and ask questions on their own.

Yes $\quad 104 \quad 92.03$

Teaching

The school encourages the involvement of students in various extracurricular and activities.

Yes

$86 \quad 76.10$

I process the teaching contents by encouraging the mental effort of the different cognitive levels of the students I teach.

Yes $\quad 107 \quad 94.69$

In my work I use strategies suitable for working with large groups (there are more than 20 students, so I use: lectures, demonstrations, Yes $\quad 92 \quad 81.41$ discussions, questions and answers and videos).

In my work I use strategies suitable for working with small groups (5-20 students, so I use: workshops, seminar, games such as "brainstorming," buzz groups, field trips, role-playing games, "ice-breakers," Yes simulations and case study).

\begin{tabular}{ccccc}
\hline Students work in pairs or groups (team work). & Yes & 107 & 94.69 \\
\hline $\begin{array}{c}\text { Homework is research assignments that follow the } \\
\text { contents covered in class. }\end{array}$ & Yes & 88 & 77.87 \\
\hline $\begin{array}{c}\text { Parts of the material that students have not } \\
\text { successfully mastered are worked on again. }\end{array}$ & Yes & 93 & 82.30 \\
\hline
\end{tabular}

I encourage the interests of students, regardless of whether they go beyond the curriculum or the $\quad$ Yes $\quad 103 \quad 91.15$ lesson.

Teaching is individualized, tasks and activities are tailored to the needs of each individual student.

Yes $\quad 62 \quad 54.86$

I work on an individualized curriculum based on getting to know what the students can do (respecting what they can't). 


\begin{tabular}{|c|c|c|c|c|}
\hline \multirow{5}{*}{ Evaluation } & $\begin{array}{l}\text { The curriculum clearly defines the assessment } \\
\text { criteria. }\end{array}$ & No & 71 & 62.83 \\
\hline & $\begin{array}{l}\text { Students and parents regularly receive information } \\
\text { about the achieved success with an explanation of the } \\
\text { facts from the cognitive, psychomotor and affective } \\
\text { levels of progress. }\end{array}$ & Yes & 99 & 87.61 \\
\hline & $\begin{array}{l}\text { Students' opinions on their own achievement are } \\
\text { considered in the assessment. }\end{array}$ & Yes & 99 & 87.61 \\
\hline & $\begin{array}{l}\text { Students have the opportunity to apply what they } \\
\text { have learned and demonstrate knowledge in a variety } \\
\text { of real-world situations. }\end{array}$ & Yes & 96 & 84.61 \\
\hline & $\begin{array}{l}\text { In the knowledge test, we always set clear tasks that } \\
\text { students should have learned from the textbook. }\end{array}$ & Yes & 99 & 87.61 \\
\hline \multirow{11}{*}{$\begin{array}{l}\text { Type of } \\
\text { curriculum }\end{array}$} & $\begin{array}{l}\text { The school has well-developed and effective links } \\
\text { with other schools and educational institutions. }\end{array}$ & Yes & 66 & 58.40 \\
\hline & $\begin{array}{l}\text { The school participates in projects proposed by the } \\
\text { local community or their initiatives }\end{array}$ & Yes & 78 & 69.02 \\
\hline & $\begin{array}{l}\text { Students, parents, teaching and non-teaching } \\
\text { employees participate in making decisions about the } \\
\text { life and work of schools. }\end{array}$ & Yes & 75 & 66.37 \\
\hline & $\begin{array}{l}\text { I participated in the development of the School's } \\
\text { Annual Programme. }\end{array}$ & No & 72 & 63.71 \\
\hline & $\begin{array}{l}\text { I participated in the development of the School's } \\
\text { Development Plan. }\end{array}$ & No & 76 & 67.25 \\
\hline & $\begin{array}{l}\text { I know what are the priority areas of development } \\
\text { planning expressed by students, parents and school } \\
\text { employees (and the same is stated in the School } \\
\text { Development Plan). }\end{array}$ & No & 61 & 53.98 \\
\hline & $\begin{array}{l}\text { Organizational strategies envisage that I am } \\
\text { professionally trained for the development of the } \\
\text { school curriculum. }\end{array}$ & No & 78 & 69.02 \\
\hline & $\begin{array}{l}\text { I can observe curricular areas based on student } \\
\text { needs. }\end{array}$ & Yes & 77 & 68.14 \\
\hline & $\begin{array}{c}\text { I consider it desirable to run the school curriculum } \\
\text { as a separate subject (regular / elective). }\end{array}$ & Sometimes & 50 & 44.2 \\
\hline & $\begin{array}{l}\text { I consider it desirable to carry out the school } \\
\text { curriculum through additional, supplementary } \\
\text { classes or extracurricular activities. }\end{array}$ & Yes & 87 & 76.99 \\
\hline & $\begin{array}{l}\text { I believe that the curriculum should only be } \\
\text { a dimension of compulsory subjects or an } \\
\text { interdisciplinary topic. }\end{array}$ & Yes & 62 & 54.86 \\
\hline
\end{tabular}

Considering that no difference was noticed in the preference of educational practice or the absence of one of the observed ones, and considering the types of curriculum, the first hypothesis, in which we assumed that "there is a representation of all types of curricula in educational practice," is accepted. Cumulative and 
individual results are additionally observed and interpreted in the continuation of the subtitle "Discussion of achieved results".

Realization of the educational process according to the type of curriculum with regard to class and subject school teachers' practice

In the second task we examined whether teachers working in class and subject teaching differ in the implementation of the educational process according to the type of curriculum. In order to examine the differences in the implementation of the educational process according to the open and closed curriculum, the non-parametric technique Mann-Whitney $U$ test was used. Table 3 provides an overview of the results.

Table 3. Mann-Whitney $U$ test to determine differences in the use of the didactic concept of the curriculum with regard to work in class or subject teaching

\begin{tabular}{ccccccc}
\hline Mann-Whitney test & $\mathbf{U}$ & $\mathbf{Z}$ & $\mathbf{P}$ & $\mathbf{R}$ & \multicolumn{2}{c}{ Median } \\
\hline Open curriculum & 771.50 & -.71 & .47 & .08 & CT & 111.00 \\
\hline & & & & & ST & 111.50 \\
\hline Closed curriculum & 691.00 & -1.45 & .14 & -.15 & CT & 40.00 \\
\hline & & & & & ST & 41.00 \\
\hline
\end{tabular}

Legend: Mann-Whitney $U$ test; $Z$ - approximations; $p$ - level of significance; $r$ magnitude of impact; Median - the median of each group

As can be seen from Table 3, no statistically significant difference was found in the implementation of the educational process according to the open type of curriculum between class teachers $(\mathrm{Md}=111, \mathrm{~N}=53)$ and subject teaching $(\mathrm{Md}=111.5, \mathrm{~N}=35), \mathrm{U}=771.50, \mathrm{Z}=-.71, p=.47, r=.08$ and the closed type of curriculum between primary school teachers $(\mathrm{Md}=40, \mathrm{~N}=53)$ and subject teaching $(\mathrm{Md}=41, \mathrm{~N}=53), \mathrm{U}=691.00, \mathrm{z}=-.1 .45, p=.14, r=-.15$. Therefore, $\mathrm{H} 2$ "Classroom and subject teachers do not differ in the implementation of the educational process according to the type of curriculum" is fully accepted.

\section{Relationship of curriculum orientations with teaching goals and learning outcomes}

In this task, we wanted to examine how much the learning outcomes and teaching goals explain the existence of a closed and open curriculum. All variables in the regression model are decomposed into the first principal component, the factorial scores are expressed in the form of regression scores. Based on the correlation matrix of the set of variables included in the regression model, it was 
determined that all predictor variables are statistically significantly correlated with the transmission and transaction curriculum. Although the correlations are statistically significant, it should be emphasized that the magnitude of the relationship is relatively high. Thus, the transactional (open) curriculum is highly correlated with the variables' orientation towards educational outcomes $(r=.879)$ and teaching goals $(r=.375)$. The transmission (closed) curriculum also correlates relatively highly with the orientation towards educational outcomes $(r=.468)$ and teaching goals $(r=.784)$. The complete correlation analysis is shown in Table 4.

Table 4. Coefficients of linear correlation between transactional and transmission curriculum and orientation towards educational outcomes and orientation towards teaching goals

\begin{tabular}{lcc}
\hline & OTEO & OTTG \\
\hline Open curriculum (transactional) & .879 & .375 \\
\hline Closed curriculum (transmission) & .468 & .784 \\
\hline
\end{tabular}

Legend: OTEO - orientation towards educational outcomes; OTTG - orientation towards teaching goals

Variables that represent an orientation towards educational outcomes and teaching goals are significantly intercorrelated. There are no conditions for violating the conditions of multicollinearity. Correlations between predictor variables do not exceed the conventional multicollinearity threshold, therefore all predictor variables are included in the regression model.

Table 5. Average values and standard deviations for open curriculum, closed curriculum, OTEO and OTTG

\begin{tabular}{ccc}
\hline Scales & M & SD \\
\hline Open curriculum (transactional) & 110.55 & 13.87 \\
\hline Closed curriculum (transmission) & 41.08 & 4.47 \\
\hline Orientation towards educational outcomes & 60.37 & 8.10 \\
Orientation towards teaching goals & 23.07 & 2.88 \\
\hline
\end{tabular}

The highest average values are on the scale of transactional (open) curriculum $(M=110.55)$ and orientation towards educational outcomes $(M=60.37)$, while the most modestly perceived scale is orientation towards teaching goals $(\mathrm{M}=$ 23.07). As in none of the two regression models significant cases of violation of the conditions of multicollinearity were registered, there is no fear that the obtained 
regression models will be overestimated. A detailed overview of collinearity diagnostics is shown in Table 6.

Table 6. Multicollinear diagnostics: tolerance coefficients and variance increase factors for regression models of open and closed curriculum assessment

\begin{tabular}{ccc}
\hline \multicolumn{3}{c}{ A set of predictor variables } \\
\hline OTEO & OTTG \\
\hline Tolerance & .854 & 1.171 \\
VIF & .854 & 1.171 \\
\hline
\end{tabular}

Table 7. General performance indicators of regression models: multiple correlation coefficients and multiple determinations

\begin{tabular}{ccccc}
\hline Model & $\mathbf{R}$ & $\mathbf{R}^{2}$ & $\Delta \mathbf{R}^{2}$ & Standard error \\
\hline Open curriculum & .88 & .76 & .77 & 6.65 \\
\hline Closed curriculum & .80 & .65 & .64 & 2.68 \\
\hline
\end{tabular}

Legend: $R$ - multiple correlation coefficient; $R 2$ - multiple determination coefficient; $\Delta R 2$ - corrected $R 2$

The most efficient model proved to be the regression solution for the score prediction model on the open curriculum scale where about $77 \%$ of the variance of this construct was explained. $\left(\mathrm{R}=.88 ; \mathrm{R}^{2}=.77\right)$. A regression model that addresses the issue of closed curriculum prediction was less useful in prediction $\left(\mathrm{R}=.80 ; \mathrm{R}^{2}\right.$ $=.64$ ), and the model explains about $64 \%$ of the variance of this construct. The summarized results of the analysis of variance with the most relevant information for all four tested models are shown in Table 8 .

Table 8. Summary indicators of variance analysis for testing regression models

\begin{tabular}{|c|c|c|c|c|c|c|}
\hline \multicolumn{2}{|c|}{ Model } & SS & Df & MS & F & $\mathbf{P}$ \\
\hline \multirow{3}{*}{$\begin{array}{c}\text { Open } \\
\text { Curriculum }\end{array}$} & Regression & 15808.56 & 2 & 7904.28 & 178.94 & .000 \\
\hline & Residual & 4593.90 & 104 & 44.17 & & \\
\hline & Total & 20402.46 & 106 & & & \\
\hline \multirow{3}{*}{ Closed curriculum } & Regression & 1374.49 & 2 & 687.24 & 95.33 & .000 \\
\hline & Residual & 749.74 & 104 & 7.20 & & \\
\hline & Total & 2124.24 & 106 & & & \\
\hline
\end{tabular}

Legend: SS - sum of squares; $d f$ - degrees of freedom; MS - average squares; F - Fisher F ratio 
Partial, i.e. the individual contribution of the variables to the regression model was estimated by overstandardized regression coefficients $\beta$. The first regression model open curriculum is statistically significantly contributed by one variable orientation towards educational outcomes ( $\beta=.86, t=17.11, p<.05)$. The second regression model of the closed curriculum resulted in both statistically significant variables, orientation towards educational outcomes $(\beta=.19, t=3.12, p<.05)$ and orientation towards teaching goals $(\beta=70, t=11.23, p<.05)$. Partial contributions of predictor variables are shown in Table 9.

Table 9. Partial contributions of predictor variables to open and closed curriculum

\begin{tabular}{rccccccc}
\hline Model & & B & Std. error & B & $\mathbf{s r}^{2}$ & $\mathbf{t}$ & $\mathbf{P}$ \\
\hline & Constant & 16.44 & 6.03 & & & 2.72 & .008 \\
\cline { 2 - 8 } Open curriculum & OTEO & 1.47 & .08 & .86 & $>.01$ & 17.11 & .000 \\
\cline { 2 - 8 } & OTTG & .22 & .24 & .05 & $>.01$ & .89 & .373 \\
\cline { 2 - 8 }
\end{tabular}

\begin{tabular}{lccccccc}
\hline & Constant & 9.17 & 2.44 & & & 3.76 & .000 \\
\cline { 2 - 8 } Closed curriculum & OTEO &.-11 & .03 & .19 & $>.01$ & 3.12 & .002 \\
\cline { 2 - 8 } & OTTG & 1.09 & .09 & .70 & $>.01$ & 11.23 & .000 \\
\hline
\end{tabular}

Legend: $B$ - non-standardized regression coefficient; Std. error - standardized beta coefficient; $s r^{2}$ - square of semi-partial correlation coefficient; $t$-Student's $t$ test.

The obtained results are in accordance with the assumed model that educational outcomes and teaching goals contribute to the explanation of open and closed curriculum. Orientation towards teaching goals contributes to the explanation of the closed curriculum, but not the open curriculum, while orientation towards educational outcomes contributes to the explanation of the variance of both the open and closed curriculum.

Based on the results of multiple regression analysis conducted on two predictor orientations towards educational outcomes and teaching goals and scales of open and closed curriculum as dependent variables, it is concluded that the obtained models explained $64 \%$ to $77 \%$ of the variance of the open and closed curriculum through orientations towards educational outcomes and teaching goals. The solution for the closed curriculum criterion proved to be more useful, and the prediction for the open curriculum proved to be the least appropriate. The third hypothesis, "Orientation to educational outcomes and teaching goals is expected to contribute to the explanation of open and closed curriculum", is accepted. 


\section{DISCUSSION OF THE ACHIEVED RESULTS}

The results on the current orientation of the curriculum in educational practice refer to the role or position of the educator. Some of the results confirm the lack of support for educators who, for example, "are not members of research and development teams, during the last year did not hold any respectable classes for their colleagues," but also that if supported by management they remain motivated to innovate the practice of the educational process.

When we talk about the planning process, educators state that they have clearly stated goals and tasks in their preparations, and that the forms for teaching preparations provide for the writing of educational outcomes. Teachers are not involved in the process of creating or changing curriculum and did not participate in professional development for them. In the teaching process, they state that teaching content is sometimes age-appropriate and adapted to the individual needs and interests of students; teachers use creative techniques in teaching; they did not use information and communication technologies before the introduction of online teaching; teaching contents are processed by encouraging the activation of different cognitive levels in students; very often they use strategies that are appropriate in working with large and small groups of students. Learning involves teaching forms, working in pairs or in groups; homework accompanies the processed contents; content that has not been successfully mastered is re-processed; student interest is encouraged; teaching is individualized, and individualized plans and programmes are additionally developed if it is additionally supported by the upbringing and education of the child.

The results related to assessment show that there are no clearly defined assessment criteria in the curriculum in relation to respecting students' opinions about their own achievements; teachers give feedback on student achievement and compliance of the examined material in accordance with that of the textbook. In accordance with the above, it is concluded that there are elements of both closed and open curriculum in educational practice, and that the first hypothesis about the representation of open and closed curriculum in the educational practice of the represented sample is confirmed: "There is a representation of all types of curriculum in the educational practice of the represented sample."

The second task was about the implementation of the educational process according to the type of curriculum. It did not show that educators differ in the way they work with regard to their jobs. Examining the orientations of educators' practices has shown their orientation towards different types of curricula, and this fact is a resource for understanding the pedagogical approach, which is basically 
the same for them. In conclusion, the same curriculum orientations are equally present in classroom and subject teaching, and one group did not show more desirable ways of working (in favor of prejudices about the criteria or opinion that one group is more dedicated to students), which is why the second hypothesis was confirmed: "Classroom and subject teachers do not differ in the implementation of the educational process according to the type of curriculum."

Research on the existence of open and closed curriculum, and the influence of orientation towards teaching goals and orientation towards educational gatherings occupies a significant place in pedagogical practice of (non) orientation towards educational outcomes or orientation towards teaching goals. In the sample of educators who do not differ in the implementation of the educational process according to the type of curriculum, there is an impact of orientation towards educational outcomes on the open curriculum, and the second model, closed curriculum, results in the impact of teaching goals and educational outcomes. The polarisation of teaching goals and educational outcomes is more evident in this case with the closed curriculum, because it implicitly focuses on the teaching content in relation to the open curriculum which advocates focus primarily on students and acquired knowledge, and less on teaching content. The planning process also speaks in favor of the lack of systemic support that does not provide for changes in administrative requirements for educators, for example, stating that $47.74 \%$ of the total sample "uses the old curriculum because the curriculum does not change" and $68.46 \%$ of respondents "do not write learning outcomes because the form for writing curriculum does not require the same." This practice "does not expect any change" if it is most desirable to direct the teaching process to educational outcomes.

The research sample shows the practice of class and subject teachers to nurture both curriculum orientations that do not exist anywhere institutionally and explicitly through laws and bylaws. Based on the practice, teachers show that we have admixtures of both closed and open characteristics, but also that there is no statistically significant difference that confirms that some have traditional practice, and that others work better and more innovatively, which confirms the third hypothesis: "Orientation to educational outcomes and teaching goals is expected to contribute to the explanation of open and closed curriculum."

The fourth research hypothesis: "Recommendations given as improvement measures through the perspective of pedagogical discourse enable the reduction of the gap between polarised orientations focused on the position of factors of the educational process," will be explained and critically presented through the proposed futuristic pedagogical discourse. To the life of the presented pedagogical 
paradigm in educational practice, i.e. its orientation towards educational teaching, we can consider that this hypothesis has not been confirmed.

Return education to schools.

\section{Recommendations in favor of the conclusion: the possibility of applying research results in the spirit of pedagogical discourse}

By analyzing the obtained research results and realizing that there is no statistically significant difference with regard to the workplace (class / subject teaching) and orientation towards open or closed curriculum, i.e. that in practice we have equal admixtures of characteristics of both closed and open curriculum, and that there is no difference in the sense that one group is more traditional or innovative than the other, we confirmed the original thinking focused on current educational standards, i.e. building competencies "or on transferring teaching content to all students or on the option to think from the end starting from the desired educational outcomes." If we consider the example of Comenius' pedagogical system (in Magna Didactica, 1632) or Herbart's draft for pedagogy (Draft lecture for pedagogy, 1833) it seems that four centuries later we live the same (innovative?) dilemma, i.e. whether teaching will be competence oriented or whether it should respond to the educational-political demand with "educational teaching that includes competencies." Starting from the theory of Herbart's "educational teaching," i.e. answering the question of what teaching should be like in times of great social changes (from a pedagogical perspective), several authors point out the shortcomings: competence-oriented teaching alone is not a sufficient condition for good teaching (Meyer, 2012, 8); competencies can be only one of, but not the highest and most important goal of teaching because there is no place for it due to the educational political perspective, let alone the realization of the process of education, which explains the phenomena present in today's society such as declining moral values (adapted Koch, 2012); the one who participates in educational teaching acquires subject (professional) knowledge and ability for further development, in order to be able to master the requirements that the world puts before him / her ..., and the role of teachers is aimed at building "moral character," values that will build multifaceted interested persons (according to Anhalt, 2009, 266) etc. However, even if we are advocates of the educationalpolitical issue, the administrative-methodological condition according to which the methodology of separate subjects is applied in educational institutions remains worrying. For example, in order to analyse the formulation of teaching goals in lesson plans and adapt them for research, Bjelopoljak i Marjanović (Guidelines..., 2021) submitted 168 lesson plans. Only nine of them had an explicitly stated, clear 
and measurable learning outcome (observed for the cognitive level), and apart from the material and functional goal, an educational goal was not repeated in all lesson plans as a remembered and appropriate motto for all educational situations (if planned at all). According to experience, we will cite Palekčić who points out that "if one knows how something works" it can be done. Therefore, the certainty of cognition lies in the approach to things - in methodology, so if one wants to know (actually explain) what education is, one must show, i.e. provide an insight into the way education works (Palekčić, 2015, 425).

Reflecting on the synthesis of recommendations that different orientations link, we will conclude the following: alternative (opposing) views of competencybased teaching should be based on the position / role of students and teachers or dilemmas about the essence of teaching through focusing on teaching goals or educational outcomes; regarding the types of curriculum, open or closed (a metaphor for all types), it seems that we still do not have clear evidence of quality about today's known teaching. If we consider the educational-political requirement imbued with PISA testing and the fact that we have every other child functionally illiterate in the nation, it seems that time and space for action have been lacking for a long time. The syllogism given in the announcement of the conclusion "Return education to schools" implies a pedagogical discourse that again reminds of educationally oriented teaching, which is the only possible counterpart to teaching oriented to competencies. If we translate this into the choices we see in pedagogical works for problems present in education, such as professional development for educators that will romantically reconcile all possible differences (see Bjelopoljak, Redžić, 2020), it would mean that we will try to equalize for many years to come in work, learning and to formulate goals / tasks that we want to realize in the teaching process. However, we still remain in a "vicious circle" that gives the same results, based on a non-pedagogical paradigm about the essence of teaching.

Finally, although the idea seems rather radical, there is a recommendation to rethink education: the essence of school (ideas in Tillmann, 1994, Palekčić, 2015), the identity of the educator through educational reform that puts into a dialectical relationship all discussions of orientations in a topic most important to society, a topic called child. 


\section{REFERENCES}

1. Anhalt, E. (2009). Der „Erziehende Unterricht“. Zur Relevanz eines historischen Konzepts für die Planung, Analyse und Kritik des Konkreten Unterrichts. In G. Mertens, U. Frost, W. Böhm, V. Ladenthin (Eds.) Handbuch der Erziehungswissenschaft, II72 - Erwachsenenbildung Weiterbildung (pp. 263-271). Paderborn: Ferdinand Schöningh.

2. Bjelopoljak, ك̌., Marjanović, M. (2021). Smjernice za integraciju HEART aktivnosti u nastavne planove i programe. Retrieved from: https://nwb.savethechildren.net/sites/nwb.savethechildren. net/files/library/Smjernice\%20za\%20integraciju\%20HEART\%20metodologije\%20-\%20WEB\%20 SPREAD\%20-\%20170321.pdf (1/7/2021)

3. Bjelopoljak, Š., Redžić, U. (2020). Kurikulum produženog boravka na osnovu realizacije odgojnoobrazovnog procesa, In S. Šušnjara, E. Dedić Bukvić (eds), Zbornik radova Odsjeka za pedagogiju: ka novim iskoracima u odgoju i obrazovanju (pp. 91-104). Sarajevo: Faculty of Humanities and Social Sciences.

4. Bratanić, M. (1993). Mikropedagogija, Interakcijsko-komunikacijski aspekt odgoja. Zagreb: Školska knjiga.

5. Bratoljub, K. (1986). Rječnik stranih riječi. Zagreb: Školska knjiga.

6. Kessler, S., Swadener, B. (1992). Reconceptualizing the Early Childhood Curriculum: Beginning the dialogue. New York: Teachers College Press.

7. Koch, L. (2012), Wissen und Kompetenz. Vierteljahresschrift für wissenschaftliche Pädagogic, 88, 454-463.

8. Meyer, H. (2012). Kompetezorientirung allein macht noch nicht einen guten Unterricht. Lernende Schule, 15 Heft, 58, 7-12.

9. Palekčić, M. (2015). Pedagogijska teorijska perspektiva, Značenje teorije za pedagogiju kao disciplinu i profesiju. Zagreb: Erudita.

10. Sekol, I., Maurović, I. (2017). Miješanje kvantitativnog i kvalitativnog istraživačkog pristupa u društvenim znanostima - miješanje metoda ili metodologija, Ljetopis socijalnog- rada, 24 (1): 7-32. Retrieved from: https://hrcak.srce.hr/file/273182 (1/7/2021)

11. Slunjski, E. (2001). Integrirani predškolski kurikulum. Zagreb: Mali profesor d.o.o.

12. Slunjski, E. (2010). Bitne značajke kurikuluma: kontekstualiziranost i razvojnost. Zrno: časopis za obitelj, vrtić i školu, (21), 116-117.

13. Tillmann, K.-J. (1994). Teorije škole. Zagreb: Educa. 


\section{PEDAGOŠKI DISKURS RAZVOJA KURIKULUMA NA OSNOVU ORIJENTACIJA ODGOJNO-OBRAZOVNE PRAKSE}

\section{SAŽETAK}

Reformom obrazovanja koja prati potrebe svih učenika, roditelja te zaposlenih u odgojno-obrazovnim ustanova podrazumijeva se kao cilju usmjereno djelovanje. Praksa koja njeguje koncept usmjeren nastavnom sadržaju i koja čak ni u pedagoškoj evidenciji ne najavljuje ishode učenja potvrduje da učenik nije subjekt odgojnoobrazovnoga procesa i da postoji mogući raskorak između teorije i prakse. Medutim, što ako ovu spoznaju vidimo kao mogućnost? Ako bismo analizu kvalitete orijentacija praksi započeli i „počevš̌i s kraja“, utvrdili bismo činjenično o ulozi svih uključenih $u$ odgojno-obrazovni proces bez, moguće nepotrebnih, polaritetnih orijentacija „za $i$ protiv". Cilj ovoga rada jest ispitati orijentaciju kurikuluma prisutnih u praksi odgojno-obrazovnih ustanova da bi se moglo zaključiti o pedagoškome diskursu kao temelju promjena. U radu su prvo operacionalizirani pojmovi s obzirom na vrste kurikuluma prisutnih u odgojno-obrazovnoj praksi, azatim se empirijskom provjerom pristupilo testiranju postavljenih hipoteza. Dobiveni rezultati istraživanja pokazuju da su podjednako zastupljene sve orijentacije kurikuluma u odgojno-obrazovnoj praksi; da se nastavnici razredne $i$ predmetne nastave ne razlikuju u realizaciji odgojno-obrazovnoga procesa prema tipu kurikuluma $i$ da orijentacija ishodima učenja i ciljevima poučavanja pridonosi u objašnjavanju otvorenoga i zatvorenoga kurikuluma. U posljednjem dijelu rada objašnjen je i kritički raspravljen pedagoški diskurs kao agens promjene u području kvalitete odgojno-obrazovne prakse na osnovi prvobitnih promišljanja o trenutnoj usmjerenosti kompetencijama kao pedagoškom standardu. Prinos istraživanju dalo je 113 prosvjetnih radnika zaposlenih u osnovnim školama odgovaranjem na kreiran e-Instrument za potrebe ovoga istraživanja.

Ključne riječi: pedagogija, kurikulum, ciljevi poučavanja, odgojno-obrazovni ishodi, pedagoški diskurs. 